\title{
Erratum to: Transthoracic mini-open approach for anterior monosegmental stabilization and fusion
}

\author{
Andreas Pingel $^{1} \cdot$ Jens Castein $^{1} \cdot$ Frank Kandziora $^{1}$
}

Published online: 3 October 2017

(c) Springer-Verlag GmbH Germany 2017

\section{Erratum to: Eur Spine J}

DOI 10.1007/s00586-017-5011-0

Unfortunately, the title of the above mentioned article was incorrectly published on the original version. The complete correct title should read as follows:

"Transthoracic mini-open approach for anterior monosegmental stabilization and fusion"

The online version of the original article can be found under doi:10.1007/s00586-017-5011-0.

Andreas Pingel

Andreas.Pingel@BGU-Frankfurt.de

1 Berufsgenossenschaftliche Unfallklinik Frankfurt, Frankfurt, Germany 